JAAKFE UNTAN

(Jurnal Audit dan Akuntansi Fakultas Ekonomi Universitas Tanjungpura)

Vol. 10 No. 1, Juni 2021

ISSN-P: (2252-7486), ISSN-E: (2746-6140)

https://jurnal.untan.ac.id/index.php/jaakfe

\title{
TINJAUAN ATAS RETRIBUSI DAERAH TERHADAP PENDAPATAN ASLI DAERAH PEMERINTAH KOTA PONTIANAK (PERIODE TAHUN 2015-2019)
}

\author{
Nella Ayu Ningrum* \\ Universitas Tanjungpura, Indonesia. \\ *E-mail: nellaayuningrum30@gmail.com
}

\begin{abstract}
Abstrak
Penelitian ini bertujuan untuk mengetahui besarnya kontribusi retribusi daerah terhadap Pendapatan Asli Daerah Kota Pontianak selama periode 5 (lima) tahun yaitu tahun 2015-2019 serta kriteria efektivitasnya. Penelitian ini menggunakan metode deskriptif atau dengan cara mengumpulkan, menyusun dan mengklasifikasikan data sehingga diperoleh gambaran yang dapat dipahami mengenai masalah yang dihadapi serta dapat ditarik sebuah kesimpulan. Penulis melakukan pengumpulan data sekunder yang diperlukan untuk penelitian. Dari hasil analisis yang telah diolah menunjukan bahwa kontribusi Pendapatan Asli Daerah Kota Pontianak dari retribusi daerah rataratanya adalah sebesar 8,91\% sisanya yaitu sebesar 91,09\% dari Pendapatan Asli Daerah bersumber dari pendapatan pajak daerah, pendapatan hasil pengelolaan kekayaan daerah yang dipisahkan dan juga pendapatan lain-lain dalam Pendapatan Asli Daerah yang sah. Tingkat efektivitas dari retribusi daerah sendiri mengalami fluktuasi dimana pada tahun 2015 mendapatkan 94,94\%, tahun 2016 mendapatkan 97,60\%, tahun 2017 mendapatkan 86,36\%, tahun 2018 mendapatkan 91,98\% dan tahun 2019 mendapatkan 104,93\%. Meskipun mengalami fluktuasi dalam 5 (lima) tahun (2015- 2019), retribusi daerah termasuk dalam kriteria efektif dengan rata-rata persentase efektivitasnya sebesar $95,16 \%$.
\end{abstract}

Kata kunci: Pendapatan Asli Daerah; Retribusi Daerah; Efektivitas.

Article History: Received:31-03-2021 Revised:04-06-2021 Accepted:09-06-2021 
Vol. 10, No. 1 (Juni 2021)

Nella Ayu Ningrum

DOI: http://dx.doi.org/10.26418/jaakfe.v10i1.46056

Hal 65-89

\section{PENDAHULUAN}

Peran otonomi daerah yang bertanggung jawab diharapkan mampu untuk membiayai suatu penyelenggaraan pemerintah di daerahnya. Oleh karena itu, Pemerintah daerah dituntut untuk lebih aktif dalam mengelola dana penerimaan pemerintah. Hukum Wagner menyatakan bahwa dalam suatu perekonomian apabila pendapatan perkapita meningkat, secara relatif pengeluaran pemerintah pun akan meningkat sebab pemerintah harus mengatur hubungan yang timbul dalam masyarakat, hukum, pendidikan, rekreasi, kebudayaan dan sebagainya (Mangkoesoebroto, 2001:17). Berdasarkan Undang-Undang No. 33 Tahun 2004 tentang Pemerintah Daerah, daerah diberikan otonomi atau kewenangan untuk mengurus urusan rumah tangganya sendiri. Salah satu bentuk kemandirian keuangan suatu daerah ditunjukkan oleh besar kecilnya Pendapatan Asli Daerah (PAD) dibandingkan dengan pendapatan daerah yang berasal dari sumber lain. Pembiayaan urusan penyelenggaraan dilakukan melalui peningkatan Pendapatan Asli Daerah. Pemerintah daerah harus berupaya mengembangkan potensi daerah dengan mengoptimalkan sumber daya yang ada untuk meningkatkan Pendapatan Asli Daerah. Realisasi Pendapatan Asli Daerah yang meningkat tentunya akan menjadi faktor pendorong kemandirian suatu daerah dalam membiayai penyelenggaraan pemerintah dan melaksanakan pembangunan. Untuk mempermudah pembangunan di suatu daerah, perlu ditetapkannya prioritas pembangunan melalui kebijakan prioritas pembangunan dan kebijaksanaan tentang anggaran. Kebijaksanaan ini akan membantu pemerintah daerah untuk menentukan target pembangunan yang dilaksanakan, mengontrol masalah keuangan daerah dan sebagai alat untuk mempengaruhi peningkatan pendapatan daerah. Selain itu untuk mendukung peningkatan Pendapatan Asli Daerah, perlu adanya kebijakan daerah melalui penetapan peraturan daerah agar tujuan akhir pemanfaatan Pendapatan Asli Daerah untuk kepentingan penyelenggaraan pemerintah dan pembangunan ekonomi dapat tercapai. Dalam Undang-Undang No. 23 Tahun 2014 tentang pemerintahan daerah, sumber pendapatan adalah berupa Pendapatan Asli Daerah (PAD) yang berasal dari:

1. Hasil pajak daerah;

2. Hasil retribusi daerah;

3. Hasil perusahaan milik daerah dan hasil pengelolaan kekayaan daerah yang dipisahkan;

4. Lain-lain pendapatan yang sah.

Salah satu komponen penting dari Pendapatan Asli Daerah adalah retribusi daerah. Retribusi daerah merupakan pembayaran wajib dari penduduk kepada negara. Hal ini dikarenakan terdapat jasa tertentu yang diberikan oleh pemerintah kepada individu secara perorangan. Sektor retribusi daerah memiliki pengelolaan yang luas karena dipungut atas balas jasa yang disediakan oleh pemerintah. Pemungutan atas retribusi daerah tersebut dapat dilakukan diluar waktu yang telah ditentukan oleh peraturan Undang-Undang, selama tersedianya jasa atas pungutan atas dasar persetujuan pemerintah pusat. Pungutan dari masyarakat ini akan menjadi sumber pendapatan bagi daerah tersebut, menjadi sumber utama pendapatan daerah selain pajak daerah, sebagai bagian laba usaha daerah maupun lain-lain Pendapatan Asli Daerah yang sah. 
Vol. 10, No. 1 (Juni 2021)

Nella Ayu Ningrum

DOI: http://dx.doi.org/10.26418/jaakfe.v10i1.46056

Hal 65-89

Penelitian terdahulu yaitu penelitian oleh Ninuk Dwiastuti, (2018) yang berjudul "Efektivitas Penerimaan Retribusi Daerah Terhadap Pendapatan Pendapatan Asli Daerah (PAD) Kabupaten/Kota di Provinsi Kalimantan Barat". Berdasarkan hasil analisis data tersebut maka dapat diperoleh kesimpulan bahwa daerah-daerah yang cukup potensial di Kalimantan Barat antara lain Pemerintah Kota Pontianak, Pemerintah Kabupaten Kubu Raya dan Kota Singkawang, yang merupakan daerah dengan sektor industri dan pariwisata yang banyak serta dapat dikenakan tarif retribusi. Dari retribusi inilah tentunya akan berperan dalam peningkatan Pendapatan Asli Daerah Provinsi Kalimantan Barat. Berdasarkan data, tingkat efektivitas penerimaan retribusi daerah Kabupaten/Kota di Provinsi Kalimantan Barat dapat dilihat pada tabel berikut ini:

Tabel 1

Rata-Rata Efektivitas Retribusi Daerah Kabupaten/Kota di Provinsi Kalimantan Barat (Periode Tahun 2010-2014)

\begin{tabular}{|l|c|c|}
\hline \multicolumn{1}{|c|}{ Kabupaten/Kota } & Efektivitas & Keterangan \\
\hline Sambas & 97,95 & Efektif \\
\hline Bengkayang & 124,75 & Sangat efektif \\
\hline Landak & 130,98 & Sangat efektif \\
\hline Mempawah & 132,39 & Sangat efektif \\
\hline Sanggau & 130,11 & Sangat efektif \\
\hline Ketapang & 128,9 & Sangat efektif \\
\hline Sintang & 129,81 & Sangat efektif \\
\hline Kapuas Hulu & 189,55 & Sangat efektif \\
\hline Sekadau & 88,72 & Cukup efektif \\
\hline Melawi & 68,51 & Kurang efektif \\
\hline Kayong Utara & 81,55 & Cukup efektif \\
\hline Kubu Raya & 135,8 & Sangat efektif \\
\hline Pontianak & 83 & Cukup efektif \\
\hline Singkawang & 92,55 & Efektif \\
\hline Rata-Rata & $\mathbf{1 1 5 , 3 3}$ & Sangat efektif \\
\hline
\end{tabular}

Sumber: Penelitian oleh Ninuk Dwiastuti, (2018) yang berjudul "Efektivitas Penerimaan Retribusi Daerah Terhadap Pendapatan Pendapatan Asli Daerah (PAD) Kabupaten/Kota di Provinsi Kalimantan Barat”.

Berdasarkan tabel tersebut, secara umum penerimaan retribusi daerah Kabupaten/Kota di Provinsi Kalimantan Barat dengan kategori sangat efektif yaitu Kabupaten Landak, Kabupaten Mempawah, Kabupaten Bengkayang, Kabupaten Ketapang, Kabupaten Sanggau, Kabupaten Sintang, Kabupaten Kapuas Hulu, dan Kabupaten Kubu Raya, sedangkan penerimaan retribusi daerah yang termasuk efektif yaitu pada Kota Singkawang dan Kabupaten Sambas. Untuk penerimaan retribusi daerah yang termasuk cukup efektif yaitu Kabupaten Kayong Utara, Kabupaten Sekadau dan Kota Pontianak, sedangkan penerimaan retribusi daerah yang termasuk dalam kategori kurang efektif adalah Kabupaten Melawi. Beberapa Kabupaten/Kota di Provinsi 
Vol. 10, No. 1 (Juni 2021)

Nella Ayu Ningrum

DOI: http://dx.doi.org/10.26418/jaakfe.v10i1.46056

Hal 65-89

Kalimantan Barat termasuk dalam kategori sangat efektif. Hal ini disebabkan target yang ditetapkan sangat kecil sehingga dapat terealisasi. Sedangkan Kabupaten/Kota di Provinsi Kalimantan Barat yang termasuk kategori cukup efektif salah satunya adalah Kota Pontianak hal ini disebabkan target yang telah ditetapkan terlalu tinggi dengan tujuan agar instansi berusaha untuk mengejar target tersebut. Tingkat efektivitas dikategorikan tinggi jika terjadi realisasi retribusi daerah berada diatas target yang telah ditetapkan dan sebaliknya apabila pencapaian realisasinya dibawah target yang telah ditetapkan maka tingkat efektivitasnya menjadi rendah. Sedangkan rata-rata di Kalimantan Barat dikategorikan sangat efektif.

Kota Pontianak merupakan daerah sentral yang menjadi acuan bagi daerah lainnya. Sumber penerimaan daerah Kota Pontianak yang sudah dikembangkan salah satunya adalah penerimaan retribusi. Retribusi merupakan harga dan suatu pelayanan langsung dari pemerintah daerah yang digunakan untuk menyediakan banyak tempat khususnya di Kota Pontianak. Beberapa tahun ini kota Pontianak sudah mengalami banyak perubahan terhadap sarana dan prasarana. Hal tersebut dapat ditetapkan sebagai peningkatan dari Pendapatan Asli Daerah. Namun, penerimaan retribusi daerah Pontianak bersifat fluktuatif yaitu ada yang naik dan juga ada yang turun. Kota Pontianak mendapat kategori cukup efektif dibandingkan daerah lain di Provinsi Kalimantan Barat. Nilai kontribusi ini dapat terus ditingkatkan dengan menemukan potensi penerimaan retribusi daerah yang baru dan memaksimalkan perolehan dari sumbersumber tersedia. Ini berarti bahwa sektor retribusi daerah memberikan pengaruh yang cukup besar untuk Pendapatan Asli Daerah kota Pontianak.

\section{LANDASAN TEORI}

\section{Akuntansi}

Definisi akuntansi adalah proses kegiatan yang mempunyai fungsi untuk menyajikan suatu informasi yang berupa angka (kuantitatif) yang bersifat keuangan dari suatu instansi maupun perusahaan yang harapannya dapat dipergunakan sebagai suatu dasar dalam menentukan dan mengambil sebuah tindakan keputusan ekonomi di dalam berbagai alternatif yang ada (Sugiono, 2014).

Pada struktur pemerintahan daerah, Satuan Kerja Perangkat Daerah (SKPD) ialah suatu entitas atau lembaga memiliki hak dan kewajiban dalam penyelenggaraan akuntansi atas transaksi-transaksi seperti penerimaan atau pendapatan, pengeluaran atau belanja, aset dan selain kas yang terdapat pada lingkungan satuan kerja. Pada jajaran pemerintah daerah satuan kerja yang mempunyai tanggung jawab dalam penyelenggaraan akuntansi ialah Satuan Kerja Pengelola Keuangan Daerah.

\section{Akuntansi Sektor Publik}

Akuntansi keuangan daerah merupakan suatu rangkaian kegiatan dalam mengidentifikasi, mengukur, mencatat, menguraikan, mengklasifikasikan, meringkas melaporkan atau menyajikan data keuangan pada daerah dalam rangka memenuhi tanggung jawab sebagai pelaksana Anggaran Pendapatan Belanja Daerah (APBD) (Mahsun, 2013).

Akuntansi sektor publik juga dapat diartikan sebagai suatu aktivitas atau kegiatan jasa yang meliputi pencatatan, pengklasifikasian dan penyajian atau pelaporan kejadian atau transaksi ekonomi yang akan memberikan hasil suatu informasi keuangan yang dibutuhkan oleh 
Vol. 10, No. 1 (Juni 2021)

Nella Ayu Ningrum

DOI: http://dx.doi.org/10.26418/jaakfe.v10i1.46056

Hal 65-89

pihak-pihak yang berkepentingan guna dalam hal pengambilan keputusan yang ditetapkan pada pengelolaan dana oleh publik pada lembaga-lembaga atau instansi tinggi suatu negara (Mardiasmo, 2009).

\section{Anggaran Sektor Publik}

Anggaran sektor publik adalah suatu tanggung jawab dari pemegang kekuasaan manajemen organisasi dalam memberikan suatu informasi tentang adanya aktivitas atau kegiatan organisasi yang ditujukan kepada pihak pemilik organisasi atas pengelolaan dana publik dan pelaksanaan yang berupa rencana program yang dianggarkan atau ditanggung dengan uang atau dana publik (Sujarweni, 2015:28).

Kemudian pokok bahasan dari anggaran ialah suatu rencana kegiatan dalam sebuah periode atau tahun yang merefleksikan bentuk rencana dari pendapatan dan belanja dalam satuan yang disebut moneter. Anggaran ini dapat berbentuk atau berupa dokumen yang menjelaskan atau menggambarkan suatu kondisi keuangan dari suatu organisasi sektor publik yang terdiri dari informasi mengenai pendapatan, belanja, dan aktivitas atau kegiatan. Anggaran yang berupa estimasi berisi tentang apa yang hendak dilakukan oleh organisasi pada masa yang mendatang.

\section{Pendapatan Asli Daerah (PAD)}

Pengertian Pendapatan Asli Daerah menurut Undang-Undang Nomor 28 Tahun 2009 yaitu sumber keuangan daerah yang digali dari wilayah daerah yang bersangkutan yang terdiri dari hasil pajak daerah, hasil retribusi daerah, hasil pengelolaan kekayaan daerah yang dipisahkan dan lain-lain pendapatan asli daerah yang sah.

Pengertian Pendapatan Asli Daerah adalah pendapatan yang bersumber dari hasil pajak daerah, hasil retribusi daerah, hasil daerah lain yang sah. Adapun tujuannya yaitu untuk memberikan keleluasaan kepada daerah dalam menggali pendanaan dalam pelaksanaan otonomi daerah sebagai perwujudan asas desentralisasi (Widiartini, 2014:28).

Pendapatan Asli Daerah adalah penerimaan yang diperoleh dari sumber- sumber dalam wilayahnya sendiri dan dipungut berdasarkan peraturan daerah sesuai dengan peraturan perundang-undangan yang berlaku (Halim, 2004:94). Pendapatan Asli Daerah ini dipungut dan diperoleh oleh daerah sesuai Peraturan Daerah (Siahaan, 2015). Dapat dijabarkan lebih lanjut berdasarkan sumber dari keduanya bahwa Pendapatan Asli Daerah berasal dari masing-masing daerah dan berperan penting dalam membangun daerah tersebut. Oleh karena itu, diharapkan setiap daerah dapat mengembangkan Pendapatan Asli Daerahnya.

Menurut Undang-Undang Nomor 33 Tahun 2004 tentang Perimbangan Keuangan antara Pusat dan Daerah pasal 1 angka 18 bahwa Pendapatan Asli Daerah merupakan pendapatan yang diperoleh dari daerah yang dipungut berdasarkan peraturan daerah sesuai dengan peraturan perundang-undangan.

Pendapatan Asli Daerah bertujuan untuk memberikan kewenangan kepada pemerintah daerah untuk membiayai atau mendanai pelaksanaan otonomi darah yang sesuai dengan potensi dan kebutuhan daerah masing-masing sebagai perwujudan desentralisasi serta pendapatan yang diterima atau diperoleh daerah bersumber dari pungutan berdasarkan pada ketentuan perundang-undangan (Pasal 3 Undang-Undang Nomor 33 Tahun 2004 tentang Perimbangan Pendapatan Asli Daerah). 
Vol. 10, No. 1 (Juni 2021)

Nella Ayu Ningrum

DOI: http://dx.doi.org/10.26418/jaakfe.v10i1.46056

Hal 65-89

Pendapatan Asli Daerah dibagi menjadi 4 (empat) jenis pendapatan (Halim, 2012:101), sebagai berikut:

1. Pajak Daerah, yang terdiri dari Pajak Provinsi dan Pajak Kabupaten/Kota;

2. Retribusi Daerah, yaitu terdiri dari Retribusi Jasa Umum, Retribusi Jasa Usaha, dan Retribusi Perizinan Tertentu;

3. Hasil perusahaan milik daerah dan hasil pengelolaan kekayaan daerah yang dipisahkan.

4. Lain-lain Pendapatan Asli Daerah yang sah, yaitu hasil penjualan kekayaan daerah yang tidak dipisahkan, hasil pemanfaatan atau pendayagunaan kekayaan daerah yang tidak dipisahkan, pendapatan bunga, jasa giro, keuntungan selisih nilai tukar mata uang rupiah terhadap mata uang asing, tuntutan ganti rugi, komisi, potongan, ataupun bentuk lain sebab penjualan dan atau pengadaan barang dan atau jasa oleh daerah.

\section{Retribusi Daerah}

Retribusi daerah adalah suatu pungutan daerah sebagai pembayaran atas jasa atau pemberian izin tertentu. Pungutan daerah ini bersifat khusus disediakan dan atau diberikan oleh pemerintah daerah untuk kepentingan pribadi atau badan (Siahaan, 2010:616).

Pengertian retribusi daerah merupakan iuran yang diberikan kepada pemerintah yang dapat dipaksakan. Iuran ini juga mendapat jasa balik secara langsung dapat ditunjuk. Paksaan dalam artian yakni bersifat ekonomis. Hal ini dikarenakan tidak semua mendapat jasa balik dari pemerintah. Bagi yang tidak mendapatkan jasa balik dari pemerintah tersebut, maka tidak dikenakan iuran (Munawir, 2011:85).

Retribusi adalah pungutan daerah yang digunakan sebagai tanda pembayaran atas jasa atau pemberian izin tertentu untuk kepentingan orang pribadi atau badan yang khusus disediakan dan atau diberikan oleh Pemerintah Daerah. Retribusi daerah sebagai sumber pendapatan daerah berkaitan dengan konsep kebijakan memungut bayaran untuk layanan dan barang yang disediakan oleh pemerintah berdasarkan efisiensi. Retribusi daerah merupakan imbalan dari pemerintah daerah atas penggunaan atau manfaat yang diperoleh secara langsung oleh seseorang atau badan hukum atas jasa nyata (Seragih, 2003:65).

Retribusi merupakan pungutan yang diberikan oleh pemerintah secara langsung dan nyata kepada pembayar yang dilakukan sehubungan dengan sesuatu jasa atau fasilitas (Muqodim, 2007:26).

Retribusi daerah merupakan suatu pembayaran dari rakyat kepada pemerintah. Dalam hal ini disertai adanya hubungan antara balas jasa langsung diterima dengan adanya pembayaran retribusi tersebut (Suparmoko, 1987:94).

Retribusi daerah merupakan pendapatan daerah yang berasal dari retribusi adalah untuk kabupaten dan kota. Retribusi ini ditetapkan sesuai dengan kewenangan masing-masing daerah yang terdiri sepuluh jenis retribusi jasa umum dan terdapat empat jenis retribusi perizinan tertentu (Halim, 2004:67).

Retribusi daerah adalah pemerintah daerah mengutip bayaran untuk layanan, berbagai surat izin, berbagai formulir dan lain sebagainya yang disediakannya. Sebagian besar pendapatan tersebut digolongkan ke dalam pungutan atau retribusi (Nick Devas, et al., 1987:94).

Retribusi merupakan harga dari suatu pelayanan langsung dari pemerintah daerah yaitu 
Vol. 10, No. 1 (Juni 2021)

Nella Ayu Ningrum

DOI: http://dx.doi.org/10.26418/jaakfe.v10i1.46056

Hal 65-89

kualitas pelayanan yang baik dan diperhatikan sesuai besarnya retribusi yang ditarik (Widjaya, 1992:80).

Retribusi adalah pungutan uang sebagai pembayaran atas jasa pekerjaan, usaha atau milik pemerintah dan berdasarkan peraturan umum. Adapun peraturan umum tersebut dibuat oleh pemerintah (Kunarjo,1996:30).

Retribusi daerah adalah suatu kebijakan pemungutan pembayaran atas barang dan layanan yang disediakan pemerintah berlandaskan efisiensi ekonomi. Penerimaan dari pemungutan adalah sumber daya untuk menaikkan produksi sesuai dengan keadaan permintaan, contohnya yaitu layanan kesehatan (Devas, 1989:134).

Undang-Undang Nomor 28 Tahun 2009 pasal 1 ayat 10 tentang Pajak Daerah dan Retribusi Daerah menyebutkan bahwa retribusi daerah adalah pungutan daerah sebagai pembayaran atas jasa atau pemberian izin tertentu yang khusus disediakan dan/atau diberikan oleh pemerintah daerah untuk kepentingan orang pribadi atau badan.

Berdasarkan definisi diatas dapat disimpukan bahwa retribusi adalah pungutan daerah yang sebagai pembayaran atas jasa yang disediakan oleh pemerintah daerah. Pemungutan retribusi atas semua yang diberikan pemerintah tidak bersifat keseluruhan melainkan hanya jenis-jenis jasa tertentu yang menurut pertimbangan sosial ekonomi layak dijadikan sebagai objek retribusi.

Keberadaan retribusi daerah berkesinambungan dengan otonomi daerah dan desentralisasi. Desentralisasi merupakan suatu media untuk mencapai salah satu tujuan bernegara yaitu memberikan pelayanan umum yang baik dan menciptakan proses pengembalian keputusan publik yang demokratis (Sidik, 2014:38).

Salah satu komponen desentralisasi adalah desentralisasi fiskal. Pemerintah Daerah harus mendapat dukungan sumber-sumber pendanaan baik yang bersumber dari Pendapatan Asli Daerah, bagi hasil pajak dan bukan pajak, pinjaman, maupun subsidi untuk melaksanakan fungsinya secara efektif dan mendapat kebebasan dalam pengambilan keputusan pengeluaran di sektor publik (Sidik, 2014:40).

Faktor- faktor pendorong pelaksanaan desentralisasi fiskal dengan baik, sebagai berikut:

1. Pemerintah pusat yang mampu melaksanakan pengawasan dan enforcement;

2. Keseimbangan dan kejelasan dalam pembagian tanggung jawab;

3. Sumber Daya Manusia (SDM) yang kuat pada pemerintah daerah guna menggantikan peran Pemerintah Pusat.

Berdasarkan Undang-Undang No. 23 Tahun 2014 bahwa salah satu sumber pendapatan daerah adalah retribusi daerah. Retribusi daerah oleh Undang-Undang Nomor 23 Tahun 2014 digolongkan dalam Pendapatan Asli Daerah. Hasil retribusi tersebut dialokasikan untuk daerah. Kemampuan self supporting dalam bidang keuangan merupakan salah satu kriteria penting untuk mengetahui secara nyata kemampuan daerah dalam mengatur dan mengurus rumah tangganya. Sehubungan dengan pentingnya posisi keuangan ini, pemerintah daerah tidak akan dapat melaksanakan fungsinya dengan efektif dan efisien tanpa biaya yang cukup untuk memberikan pelayanan dan pembangunan dan keuangan (Kaho, 2004:138). Salah satu dasar kriteria untuk mengetahui secara nyata kemampuan daerah dalam mengurus rumah tangganya sendiri melalui besar kecilnya Pendapatan Asli Daerah (PAD) dibandingkan dengan pendapatan 
Vol. 10, No. 1 (Juni 2021)

Nella Ayu Ningrum

DOI: http://dx.doi.org/10.26418/jaakfe.v10i1.46056

Hal 65-89

daerah yang berasal dari sumber lain.

\section{Perbedaan antara Pajak dengan Retribusi Daerah}

Secara teoritis, kabupaten atau kota retribusi harus mempunyai peranan atau kontribusi yang lebih besar terhadap Pendapatan Asli Daerah (PAD). Oleh sebab itulah, kontribusi retribusi terhadap penerimaan Pendapatan Asli Daerah pemerintah kabupaten atau pemerintah kota yang relatif penting mendapat perhatian lebih bagi daerah. Pada prinsipnya retribusi sama dengan pajak. Pajak memiliki perbedaan dengan retribusi daerah. Adapun perbedaan antara pajak dan retribusi yaitu:

a. Pembayar pajak tidak menerima imbalan langsung sedangkan pembayar retribusi menerima imbalan atau manfaat dari penerima retribusi.

b. Pada retribusi berlaku sistem official assessment sedangkan pada pajak berlaku sistem self assessment, official assessment, dan withholding.

c. Objek pajak bukan merupakan objek retribusi.

\section{Ciri-Ciri Retribusi Daerah}

Secara umum ciri ciri retribusi daerah, yaitu:

a. Retribusi dipungut oleh pemerintah daerah;

b. Terdapat kontraprestasi yang secara langsung dapat ditunjuk;

c. Dalam pemungutan terdapat paksaan secara ekonomis; dan

d. Retribusi dikenakan pada setiap orang atau badan yang menggunakan atau mengenyam jasa-jasa yang disiapkan negara.

\section{Jenis-Jenis Retribusi Daerah}

Jenis-jenis retribusi dapat dikelompokkan ke dalam 3 (tiga) golongan, yaitu sebagai berikut:

1. Retribusi Jasa Umum, yaitu retribusi atas jasa pelayanan yang disediakan oleh pemerintah daerah. Tujuannya adalah untuk kepentingan dan kemanfaatan umum serta dapat dinikmati oleh orang pribadi atau badan. Jenis retribusi jasa umum adalah:

1) Retribusi Pelayanan Kesehatan;

2) Retribusi Pelayanan Persampahan atau kebersihan;

3) Retribusi Pelayanan Pasar;

4) Retribusi Pengujian Kendaraan Bermotor;

5) Retribusi Pelayanan Parkir Tepi Jalan Umum;

6) Retribusi Pemeriksaan Alat Pemadam Kebakaran;

7) Retribusi Penggantian Biaya Cetak Peta;

8) Retribusi Penggantian Biaya Cetak Kartu Penduduk dan Penggantian Biaya Cetak Akta Catatan Sipil;

9) Retribusi Pengujian Kapal Perikanan.

2. Retribusi Jasa Usaha, yaitu retribusi yang dikenakan atas jasa pelayanan yang disediakan oleh pemerintah daerah. Retribusi ini menganut prinsip komersial, yang terdiri dari:

1) Pelayanan oleh Pemerintah Daerah selama belum memadai disediakan oleh pihak swasta;

2) Pelayanan yang menggunakan atau memanfaatkan kekayaan daerah yang belum dimanfaatkan secara optimal. 
Vol. 10, No. 1 (Juni 2021)

Nella Ayu Ningrum

DOI: http://dx.doi.org/10.26418/jaakfe.v10i1.46056

Hal 65-89

Jenis-jenis Retribusi Jasa Usaha adalah:

1) Retribusi Tempat Pelelangan;

2) Retribusi Terminal;

3) Retribusi Tempat Khusus Parkir;

4) Retribusi Pemakaian Kekayaan Daerah;

5) Retribusi Pasar Grosir dan/atau Pertokoan;

6) Retribusi Rumah Potong Hewan;

7) Retribusi Pelayanan Pelabuhan;

8) Retribusi Tempat Rekreasi dan Olah Raga;

9) Retribusi Penyeberangan;

10) Retribusi Pengolahan Limbah Cair;

11) Retribusi Penjualan Produksi Usaha Daerah;

12) Retribusi Tempat Penginapan/Pesanggrahan/Villa;

13) Retribusi Penyediaan Kakus.

3. Retribusi Perizinan, yaitu retribusi yang dikenakan atas pemberian izin dari pemerintah daerah kepada orang pribadi atau badan yang melakukan aktivitas tertentu yang bertujuan untuk pembinaan, pengaturan, pemanfaatan ruang publik, penggunaan sumber daya alam, barang, sarana dan prasarana, atau fasilitas tertentu yang dapat melindungi kepentingan umum dan menjaga kelestarian lingkungan. Jenis retribusi perizinan untuk daerah Provinsi dan daerah Kabupaten atau Kota ditetapkan sesuai dengan kewenangan masingmasing daerah. Jenis-jenis retribusi perizinan adalah:

1) Retribusi Izin Mendirikan Bangunan;

2) Retribusi Izin Trayek;

3) Retribusi lzin Gangguan.

\section{Tujuan Retribusi Daerah}

Tujuan retribusi daerah mempunyai persamaan pokok dengan tujuan pemungutan pajak yang dilakukan oleh negara atau pemerintah daerah. Adapun tujuan pemungutan tersebut adalah:

a. Tujuan utama adalah untuk mengisi kas negara atau kas daerah yang digunakan untuk memenuhi kebutuhan rutinnya.

b. Tujuan tambahan adalah untuk mengatur kemakmuran masyarakat melalui jasa yang diberikan kepada masyarakat secara langsung.

Selain jenis-jenis retribusi daerah yang ditetapkan dalam Undang-Undang Nomor 28 Tahun 2009, yaitu retribusi jasa umum, jasa usaha dan perizinan, kepada daerah diberikan kewenangan untuk menetapkan jenis retribusi daerah lainnya yang dipandang sesuai untuk daerahnya. Undang-Undang Nomor 28 Tahun 2009 menentukan bahwa dengan peraturan daerah dapat ditetapkan jenis retribusi daerah lainnya sesuai dengan kewenangan otonominya dan memenuhi kriteria yang telah ditetapkan.

\section{Kontribusi Retribusi}

Kontribusi digunakan untuk mengetahui sejauh mana retribusi daerah memberikan sumbangan dalam penerimaan Pendapatan Asli Daerah (Halim 2010). Analisis kontribusi merupakan suatu analisis yang digunakan untuk mengetahui seberapa besar kontribusi yang 
Vol. 10, No. 1 (Juni 2021)

Nella Ayu Ningrum

DOI: http://dx.doi.org/10.26418/jaakfe.v10i1.46056

Hal 65-89

diberikan dari penerimaan retribusi daerah terhadap Pendapatan Asli Daerah. Besar kontribusi ini dapat dicari dengan membandingkan penerimaan retribusi daerah dengan penerimaan Pendapatan Asli Daerah. Semakin besar nilai kontribusinya menunjukkan semakin besar pula peranan retribusi daerah dalam meningkatkan pendapatan asli daerah.

Menghitung kontribusi dilakukan dengan membandingkan penerimaan retribusi daerah periode tertentu dengan penerimaan Pendapatan Asli Daerah (PAD) juga dalam periode tertentu. Jika hasil perhitungan tersebut besar berarti besar pula peranan retribusi daerah terhadap Pendapatan Asli Daerah. Sebaliknya jika hasil perbadingannya kecil berarti peranan retribusi daerah terhadap Pendapatan Asli Daerah (PAD) juga kecil. Kontribusi dapat dihitung dengan menggunakan rumus berikut (Mahmudi, 2005):

$$
\text { Kontribusi PAD }=\frac{\text { Kontribusi Retribusi }}{P A D} \times 100 \%
$$

Dana bagi hasil retribusi dalam memberikan kontribusi dapat diketahui melalui kategori baik apabila rasio yang dicapai minimal 50\%. Pengukuran nilai kontribusi secara terperinci yaitu ke dalam 6 (enam) tingkat sebagai berikut:

Tabel 2

Klasifikasi Kriteria Kontribusi Persentase Retribusi Daerah

\begin{tabular}{|c|c|}
\hline Persentase & Kriteria \\
\hline $0 \%-10 \%$ & Sangat Kurang \\
\hline $10 \%-20 \%$ & Kurang \\
\hline $20 \%-30 \%$ & Sedang \\
\hline $30 \%-40 \%$ & Cukup Baik \\
\hline $40 \%-50 \%$ & Baik \\
\hline$\geq 50 \%$ & Sangat Baik \\
\hline
\end{tabular}

Sumber: Kepmendagri No.690.900.327 Tahun 1996.

\section{METODE PENELITIAN}

\section{Bentuk Penelitian}

Metode yang digunakan dalam penelitian ini adalah metode deskriptif. Metode deskriptif merupakan penelitian yang bersifat menjelaskan dan menggambarkan suatu keadaan atau suatu objek (Nazir, 2005). Metode deskriptif adalah metode yang digunakan untuk menganalisis atau menggambarkan suatu hasil penelitian. Fokus metode deskriptif yaitu fenomena atau masalahmasalah yang ada pada saat penelitian yang bersifat aktual. Dari fenomena atau masalahmasalah yang diselidiki tersebut digambarkanlah fakta-fakta sebagaimana diiringi dengan interpretasi rasional yang akurat (Nawawi, 1990:64). Adapun yang menjadi pokok pembahasannya adalah hasil dari perhitungan efektivitas dan kontribusi. Sesuai dengan tujuan penelitian ini yaitu menggambarkan dan mengekplorasi retribusi daerah terhadap Pendapatan Asli Daerah Kota Pontianak. Oleh karena itu, penulis menggunakan metode deskriptif untuk menggambarkan dan menggunakan data yang telah diperoleh untuk mengetahui seberapa besar kontribusi pendapatan retribusi daerah dan tingkat efektivitasnya terhadap Pendapatan Asli Daerah, kemudian membuat kesimpulan berdasarkan hasil tersebut. Hal ini tentunya bertujuan 
Vol. 10, No. 1 (Juni 2021)

Nella Ayu Ningrum

DOI: http://dx.doi.org/10.26418/jaakfe.v10i1.46056

Hal 65-89

sebagai tinjauan perspektif kemajuan perekonomian daerah khususnya Kota Pontianak.

\section{Tempat dan Waktu Penelitian}

Penelitian dilakukan di Kota Pontianak Provinsi Kalimantan Barat. Data yang diperoleh dari Kantor Badan Keuangan Daerah Pontianak untuk periode 2015-2019. Penelitian ini direncanakan akan dilaksanakan selama kurun waktu 2 (dua) bulan mulai dari penyusunan proposal penelitian, pengumpulan data hingga laporan hasil penelitian. Penelitian dilakukan pada bulan Desember 2020 sampai dengan Februari 2021.

\section{Sumber Data}

Data merupakan fakta yang tidak sedang digunakan dalam suatu proses keputusan. Biasanya data dicatat dan diarsipkan tanpa maksud. Tujuannya untuk segera diambil kembali sebagai dasar pengambilan keputusan (Kumorotomo dan Margono, 2010:11).

Penelitian ini menggunakan data kuantitatif yaitu data yang diinterpretasikan dalam bentuk angka. Data yang digunakan dalam penelitian ini adalah data sekunder yaitu data yang bersumber dari pihak lain yang diolah melalui dokumen- dokumen yang berkaitan dengan penelitian (bersumber dari literatur dan media internet). Data sekunder dalam penelitian ini meliputi:

1. Data keuangan dari Badan Keuangan Daerah di Provinsi Kalimantan Barat;

2. Data Badan Pusat Statistik; serta

3. Hasil-hasil penelitian sebelumnya.

Penelitian ini menggunakan teknik pengumpulan data sebagai berikut:

1. Pengumpulan data melalui studi dokumentasi. Studi dokumentasi adalah catatan penting peristiwa atau fenomena yang telah berlalu. Dokumen dapat berupa gambar, tulisan, atau karya monumental dari seseorang (Sugiyono, 2017). Dalam penelitian ini studi dokumentasi dilakukan dengan mempelajari dokumen atau data yang relevan dan sesuai fakta untuk kebutuhan penelitian yang berupa Laporan Realisasi Anggaran Pendapatan dan Belanja Pemerintah Kota Pontianak (Periode Tahun 2015-2019) yang digunakan sebagai sampel.

2. Pengumpulan data melalui studi literatur. Studi Literatur adalah tahapan yang urgent atau penting dimana setelah peneliti menempatkan topik dalam penelitian, kemudian tahapan selanjutnya ialah kajian terkait dengan teori yang sesuai dengan topik bahasan penelitian (Moch. Nazir, 2019). Pada penelitian ini studi literatur dilakukan dengan mempelajari buku teks bacaan dan artikel ilmiah serta penelitian lainnya yang relevan terkait dengan topik bahasan pada penelitian yang diambil sebagai sampel, terutama yang berkaitan dengan pengaruh Retribusi Daerah terhadap Pendapatan Asli Daerah.

3. Pengumpulan data melalui pemilahan materi berdasarkan kajian yang dibutuhkan dan pengambilan data dari media massa atau perangkat lunak (software) yang dikaji kembali untuk dipertanggungjawabkan dengan sistematis dan sesuai dengan topik pembahasan.

\section{Populasi dan Sampel}

Populasi dalam penelitian ini sama dengan sampel yaitu target dan realisasi retribusi Daerah Kota Pontianak. Adapun target dan realisasi yang digunakan berdasarkan pada data yang tertera dalam Laporan Keuangan Tahun Anggaran 2015-2019 yaitu pada Laporan Realisasi Anggaran Pendapatan dan Belanja Pemerintah Kota Pontianak Tahun 2015-2019 atau dalam masa periode 5 (lima) tahun. 
Vol. 10, No. 1 (Juni 2021)

Nella Ayu Ningrum

DOI: http://dx.doi.org/10.26418/jaakfe.v10i1.46056

Hal 65-89

\section{Variabel Penelitian}

Variabel penelitian merupakan suatu konsep yang dipilih untuk diteliti dan diuji kebenarannya secara empirik. Variabel penelitian juga memiliki pengaruh yang jika diukur akan menghasilkan skor yang bervariasi. Variabel merupakan gejala yang menjadi fokus penelitian (Sugiyono, 2000:34). Adapun yang menjadi variabel dalam penelitian ini adalah:

a. Variabel Terikat (Dependen)

Variabel terikat adalah variabel yang dipengaruhi atau yang menjadi akibat. Hal ini dikarenakan adanya variabel independen (Idrus, 2007:106). Dalam penelitian ini yang menjadi variabel independen adalah Pendapatan Asli Daerah (PAD).

b. Variabel Bebas (Independen)

Variabel bebas adalah variabel yang menjadi sebab berubahnya atau timbulnya variabel terikat (dependen) (Idrus, 2007:105). Berdasarkan pengertian diatas yang menjadi variabel bebas dalam penelitian ini adalah Retribusi Daerah.

\section{Metode Analisis}

Penelitian ini menggunakan metode deskriptif dengan cara menggambarkan suatu fenomena atau permasalahan yang didasari oleh data-data. Hasil analisis tersebut menjadi sebuah kesimpulan (Rumidi, 2004).

Model pendekatan yang digunakan dalam penelitian ini adalah pendekatan kualitatif. Setelah data dikumpulkan maka akan dilakukan proses analisis data untuk mengukur hasil penelitian. Adapun langkah-langkah untuk memperoleh hasil analisis dalam penelitian ini, yaitu:

1. Melakukan pengumpulan data berupa Laporan Keuangan Tahun Anggaran 2015-2019 yaitu pada Laporan Realisasi Anggaran Pendapatan dan Belanja Pemerintah Kota Pontianak Tahun 2015-2019.

2. Mendeskripsikan mengenai hasil pengumpulan data tentang pengelolaan penerimaan retribusi daerah dan Pendapatan Asli Daerah Tahun 2015-2019.

3. Menganalisis Realisasi Anggaran Penerimaan Retribusi Daerah Tahun 2015- 2019 berdasarkan kontribusi dan efektivitas retribusi daerah dengan menggunakan alat berupa rumus kontribusi Pendapatan Asli Daerah dan rasio efektivitas.

4. Pengambilan kesimpulan.

\section{HASIL DAN PEMBAHASAN}

\section{Pengelolaan Keuangan Daerah Kota Pontianak}

Pengelolaan Keuangan Daerah Pemerintah Kota Pontianak Tahun 2015 dilaksanakan berdasarkan Peraturan Pemeritah Nomor 58 Tahun 2005 tentang pengelolaan Keuangan Daerah, Peraturan Menteri Dalam Negeri Nomor 13 Tahun 2006 tentang Pedoman Pengelolaan Keuangan Daerah sebagaimana telah diubah beberapa kali terakhir dengan Peraturan Menteri Dalam Negeri Nomor 21 Tahun 2011 tentang Perubahan Kedua Peraturan menteri Dalam Negeri Nomor 3 Tahun 2006 tentang Pedoman Pengeloaan Keuangan Daerah. Peraturan Daerah Nomor 01 Tahun 2015 tentang Perubahan Atas Peraturan Daerah Nomor 3 Tahun 2010 tentang Pokok-Pokok Pengelolaan Keuangan Daerah Nomor 3 Tahun 2010. Dalam Peraturan Walikota Pontianak Nomor 56 Tahun 2015 tentang Perubahan Ketiga atas Peraturan Walikota Pontianak 
Vol. 10, No. 1 (Juni 2021)

Nella Ayu Ningrum

DOI: http://dx.doi.org/10.26418/jaakfe.v10i1.46056

Hal 65-89

Nomor 47 Tahun 2011 tentang Sistem dan Prosedur Pengelolaan Keuangan Keuangan Pemerintah Kota Pontianak, serta Peraturan Walikota Pontianak Nomor 91 Tahun 2019 tentang Perubahan Kelima atas Peraturan Walikota Nomor 62 Tahun 2013 tentang Kebijakan Akuntansi Pemerintah Kota Pontianak.

\section{Peranan Retribusi Daerah Terhadap Pendapatan Asli Daerah Pemerintah Kota Pontianak dan Upaya Peningkatannya}

Pembangunan di Indonesia masih terus dilaksanakan. Pembangunan ini meliputi segala bidang aspek kehidupan, yang pada hakikatnya menciptakan suatu masyarakat yang adil dan makmur bagi bangsa Indonesia. Upaya mewujudkan kesejahteraan rakyat agar semakin adil dan merata harus terus ditingkatkan, pertumbuhan ekonomi harus ditingkatkan melalui upaya nyata dalam bentuk perbaikan pendapatan dan peningkatan daya beli masyarakat. Pembangunan yang berhasil dirasakan oleh rakyat sebagai perbaikan tingkat taraf hidup pada segenap golongan masyarakat akan meningkatkan kesadaran mereka akan arti penting pembangunan dan mendorong masyarakat berperan aktif dalam pembangunan.

Retribusi daerah sebagaimana halnya pajak daerah merupakan salah satu Pendapatan Asli Daerah yang diharapkan menjadi salah satu sumber pembiayaan penyelenggaraan pemerintahan dan pembangunan daerah, untuk meningkatkan dan memeratakan kesejahteraan masyarakat.

Dalam Undang-Undang Nomor 34 Tahun 2000 tentang Pajak Daerah dan Retribusi Daerah menetapkan ketentuan-ketentuan pokok yang memberikan pedoman kebijaksanaan dan arahan bagi daerah dalam pelaksanaan pemungutan Pajak Daerah dan Retribusi Daerah, juga menetapkan pengaturan yang cukup rinci untuk menjamin prosedur umum perpajakan dan retribusi daerah. Penyelenggaraan Pemerintah Daerah sebagai subsistem pemerintah negara dimaksudkan untuk meningkatkan daya guna dan hasil guna penyelenggaraan pemerintah dan pelayanan masyarakat sebagai daerah otonomi.

Dalam rangka mengoptimalisasikan Pendapatan Asli Daerah, Kota Pontianak juga menjadikan sektor pajak daerah dan retribusi daerah sebagai sumber keuangan yang dapat diandalkan. Sektor pajak daerah tersebut meliputi Pajak Hotel, Pajak Restoran, Pajak Hiburan, Pajak Reklame, Pajak Penerangan Jalan, Pajak Parkir, Pajak Sarang Burung Walet, Pajak Bumi dan Bangunan Pedesaan dan Perkotaan, Bea Perolehan Hak atas Tanah dan Bangunan (BPHTB) serta Retribusi Daerah yang terdiri: Retribusi Jasa Umum, Jasa Usaha dan Retribusi Perijinan tertentu merupakan sektor yang sangat besar untuk digali dan diperluas pengelolaannya. Keberadaan retribusi daerah tidak terlepas dari diterapkannya otonomi daerah dan desentralisasi. Desentralisasi merupakan sebuah alat untuk mencapai salah satu tujuan bernegara, khususnya dalam rangka memberikan pelayanan umum yang lebih baik dan menciptakan proses pengembalian keputusan publik yang lebih demokratis. Retribusi daerah, yang selanjutnya disebut retribusi, adalah pungutan daerah sebagai pembayaran atas jasa atau pemberian izin tertentu yang khusus disediakan dan atau diberikan oleh pemerintah daerah untuk kepentingan orang pribadi atau badan. Tujuan pungutan retribusi daerah sebagaimana ditegaskan oleh konsideran Undang-Undang Nomor 28 Tahun 2009 untuk membiayai pelaksanaan otonomi daerah. Tujuan retribusi menurut Undang-Undang Nomor 18 Tahun 1997 memang memiliki sedikit perbedaan dengan tujuan retribusi menurut Undang- Undang Nomor 28 Tahun 2009, hal ini disebabkan pada tahun 1997 sistem pemerintahaan masih tersentralisasi, 
Vol. 10, No. 1 (Juni 2021)

Nella Ayu Ningrum

DOI: http://dx.doi.org/10.26418/jaakfe.v10i1.46056

Hal 65-89

walaupun ketika itu sudah dikenal sebutan otonomi daerah, tapi belum terdesentralisasi seperti saat ini. Berdasarkan Laporan Realisasi Anggaran Retribusi Daerah Pemerintah Kota Pontianak Periode 2015- 2019 yang termuat dalam daftar lampiran 6-10, berikut Satuan Kerja Perangkat Daerah (SKPD) dan beberapa retribusi dari SKPD tersebut yang menyumbang Pendapatan Asli Daerah:

1. Dinas Pendidikan dan Kebudayaan.

2. Dinas Kesehatan (Retribusi Pelayanan Kesehatan Pelayanan Kesehatan di Puskesmas).

3. Dinas Pekerjaan Umum (Retribusi Pemakaian Kekayaan Daerah yaitu Peralatan dan Mesin).

4. Dinas Perumahan Rakyat dan Kawasan Permukiman (Retribusi Izin Mendirikan Bangunan).

5. Badan Perencanaan Pembangunan Daerah.

6. Dinas Perhubungan (Retribusi Pelayanan Parkir di Tepi Jalan Umum yaitu Penyediaan Pelayanan Parkir di Tepi Jalan Umum, Retribusi Pengujian Kendaraan Bermotor, Retribusi Pemakaian Kekayaan Daerah yaitu Penyewaan Tanah dan Bangunan, Retribusi Terminal yaitu Pelayanan Penyediaan Tempat Parkir untuk Kendaraan Penumpang yaitu Bis Umum dan Fasilitas Lainnya di Lingkungan Terminal, Retribusi Pelayanan Kepelabuhan yaitu Pelayanan Jasa ke Pelabuhan, Retribusi Penyeberangan Air yaitu Pelayanan Penyeberangan Orang dan Pelayanan Penyeberangan Barang.).

7. Dinas Komunikasi dan Informatika (Retribusi Pengendalian Menara Telekomunikasi).

8. Dinas Lingkungan Hidup (Retribusi Pelayanan Persampahan/Kebersihan yaitu Pengangkutan Sampah dari Sumbernya dan/atau Lokasi Pembuangan Sementara ke Lokasi Pembuangan Akhir Sampah, Retribusi Penyediaan dan/atau Penyedotan Kakus yaitu Penyediaan dan/atau Penyedotan Kakus, Retribusi Pemakaian Kekayaan Daerah yaitu Laboratorium).

9. Dinas Pengendalian Penduduk, Keluarga Berencana dan Perlindungan Anak.

10.Dinas Kependudukan dan Pencatatan Sipil (Retribusi Penggantian Biaya Cetak Kartu Tanda Penduduk dan Akta Catatan Sipil, Retribusi Pelayanan Pemakaman dan Penggabungan Mayat).

11.Dinas Sosial.

12.Badan Penanggulangan Bencana Daerah (Retribusi Pemeriksaan Alat Pemadam Kebakaran).

13.Dinas Koperasi, Usaha Mikro, dan Perdagangan (Retribusi Pelayanan Pasar, Retribusi Harian, Retribusi Bulanan, Retribusi Izin Pemindahan Hak- Penunjukkan Baru, Herregistrasi, dan Retribusi Pemakaian Kekayaan Daerah).

14.Dinas Penanaman Modal Tenaga kerja dan Pelayanan Terpadu Satu Pintu (Retribusi Izin Mendirikan Bangunan yaitu Pemberian Izin Mendirikan Bangunan, Retribusi Izin Gangguan, Retribusi Izin Gangguan/Keramaian (HO), Retribusi Izin Perikanan, Retribusi Izin Usaha Perikanan).

15.Dinas Kepemudaan, Olahraga dan Pariwisata (Retribusi Pemakaian Kekayaan Daerah yaitu Pendapatan dari Pemakaian Lapangan Olahraga).

16.Dinas Perpustakaan. 
Vol. 10, No. 1 (Juni 2021)

Nella Ayu Ningrum

DOI: http://dx.doi.org/10.26418/jaakfe.v10i1.46056

Hal 65-89

17.Dinas Pangan, Pertanian dan Perikanan (Retribusi Pemakaian Kekayaan Daerah yaitu Penyewaan Tanah dan Bangunan, Retribusi Tempat Pelelangan yaitu Jasa Pelelangan serta Fasilitas Lainya yang disediakan di Tempat Pelelangan, Retribusi Rumah Potong Hewan yaitu Pelayanan Pemeriksaan Kesehatan Hewan Sebelum dan Sesudah dipotong, Retribusi Izin Perikanan yaitu Pemberian Izin Usaha Perikanan kepada Orang Pribadi dan Pemberian Izin Usaha Perikanan kepada Badan).

18.Badan Keuangan Daerah (Retribusi Pemakaian Kekayaan Daerah yaitu Penyewaan Tanah dan Bangunan).

19.Badan Kepegawaian Daerah dan Pengembangan Sumber Daya Manusia.

20.Kantor Kesatuan Bangsa dan Sosial Politik.

21.Satuan Polisi Pamong Praja (Retribusi Pemeriksaan Alat Pemadam Kebakaran yaitu Pelayanan Pemeriksaan dan/atau Pengujian Alat Pemadam Kebakaran).

22.Dewan Perwakilan Rakyat Daerah.

23.Sekretariat Dewan Perwakilan Rakyat Daerah.

24.Kepala Daerah dan Wakil Kepala Daerah.

25.Sekretariat Daerah.

26.Inspektorat.

27. Kecamatan Pontianak Barat.

28. Kecamatan Pontianak Timur.

29.Kecamatan Pontianak Selatan.

30.Kecamatan Pontianak Utara.

31.Kecamatan Pontianak Kota.

32.Kecamatan Pontianak Tenggara.

33.Badan Pemberdayaan Masyarakat Perempuan Anak dan Keluarga Berencana.

34.Badan Pengelolaan Keuangan dan Aset Daerah (Retribusi Pemakaian Kekayaan Daerah yaitu Penyewaan Tanah dan Bangunan).

35.Dinas Pendapatan Daerah.

36.RSUD Sultan Syarif Mohamad Alkadrie.

37.Kantor Ketahanan Pangan dan Penyuluhan.

Pengelolaan Pendapatan Asli Daerah Pemerintah Kota Pontianak diarahkan pada sumbersumber pendapatan yang selama ini telah menjadi sumber penerimaan kas daerah dengan tetap mengupayakan sumber-sumber pendapatan baru. Kebijakan Kota Pontianak akan terus berupaya menggali potensi pendapatan daerah guna meningkatkan kemmpuan fiskal pemerintah daerah. Kebijakan tersebut melalui peningkatan penggalian potensi Pendapatan Asli Daerah baik secara intensifikasi maupun ekstensifikasi tanpa mengabaikan sektor dunia usaha, yang diikuti pula dengan peningkatan kualitas pelayanan kepada wajib pajak dan retribusi daerah serta mengoptimalkan penerimaan daerah yang berasal dari dana perimbangan dan lain-lain pendapatan yang sah melalui koordinasi dengan pemerintah pusat dan pemerintah Provinsi Kalimantan Barat. Untuk mewujudkan pencapaian target dan optimalisasi pajak daerah dan retribusi berbagai upaya telah dilakukan yaitu:

1. Intensifikasi dan ekstensifikasi pajak daerah dan retribusi daerah serta lain-lain pendapatan daerah yang sah sesuai dengan potensi pungutan. 
Nella Ayu Ningrum

DOI: http://dx.doi.org/10.26418/jaakfe.v10i1.46056

Hal 65-89

2. Menyelenggarakan pelayanan prima melalui pengadaaan sarana prasarana yang memberikan kenyamanan dan keamanan serta memberikan pelayanan yang cepat dan sederhana dengan didukung teknologi informasi yang memadai.

3. Melaksanakan peninjauan dan penilaian kembali terhadap sistem dan peraturan perundangundangan yang menghambat kelancaran penerimaan pendapatan daerah.

4. Pengembangan kelembagaan, sistem dan Operasional Pemungutan Pendapatan Daerah.

5. Pengembangan koordinasi secara sinergis dibidang Pendapatan Daerah dengan Pemerintah Provinsi, OPD (Organisasi Perangkat Daerah) terkait, serta mitra kerja seperti POLRI, Jasa Raharja, dan Unit Kerja terkait lainnya untuk mengoptimalkan penerimaan pendapatan dan pelayanan masyarakat.

6. Mengoptimalkan kinerja Badan Usaha Milik Daerah agar memberikan kontribusi Pendapatan kepada Pemerintah Daerah.

7. Memanfaatkan teknologi informasi dalam meningkatkan pemberian pelayanan perizinan.

Adapun dalam upaya meningkatkan pajak dan retribusi daerah untuk mencapai terget

Pendapatan Asli Daerah melalui intensifikasi dan ekstensifikasi sebagai berikut:

1. Intensifikasi Pajak dan Retribusi Daerah, dilakukan melalui penyederhanaan proses administrasi pemungutan dan penyempurnaan sistem pelayanan pajak dan retribusi daerah, sosisalisasi dan penyuluhan kepada masyarakat mengenai ketentuan pajak dan retribusi daerah, peningkatan koordinasi dan kerjasama antar unit Satuan Kerja Perangkat Daerah pengelola penerimaan pajak dan retribusi daerah, meningkatkan kesadaran wajib pajak dan retribusi daerah dan penegakan sanksi kepada wajib pajak daerah yang tidak melaksanakan kewajibannya.

2. Ekstensifikasi Pajak dan Retribusi Daerah, dilakukan melalui pengkajian terhadap jenis retribusi baru yang akan dijadikan objek baru, pengkajian jenis retribusi yang tidak layak dan perlu dihapuskan sehingga tidak kontra produktif dengan prekonomian daerah dan peningkatan bagi hasil pajak.

\section{Analisis Data Pendapatan Asli Daerah Kota Pontianak (Periode Tahun 2015-2019)}

Salah satu sumber penerimaan daerah adalah berupa Pendapatan Asli Daerah (PAD), dimana Pendapatan Asli Daerah merupakan bagian dari sumber pendapatan daerah yang secara bebas dapat digunakan oleh masing-masing daerah untuk menyelenggarakan pemerintahan dan pembangunan daerah. Pertumbuhan komponen Pajak Daerah, Retribusi Daerah, Hasil Pengelolaan Kekayaan Daerah yang dipisahkan dan lain lain Pendapatan Asli Daerah yang sah akan menjadi faktor yang penting dalam mendorong pertumbuhan Pendapatan Asli Daerah. Sedangkan untuk Dana Perimbangan, komponen Bagi Hasil Pajak serta komponen Bagi Hasil Pajak dan Bantuan Keuangan Provinsi adalah dua unsur yang cukup penting dalam mendorong pertumbuhan Dana Perimbangan yang akan diperoleh nantinya. Pendapatan daerah dalam struktur Anggaran Pendapatan Belanja Daerah masih merupakan elemen yang cukup penting peranannya baik untuk mendukung penyelenggaraan pemerintahan maupun pemberian pelayanan kepada publik. Apabila dikaitkan dengan pembiayaan, maka pendapatan daerah masih merupakan alternatif pilihan utama dalam mendukung program dan kegiatan penyelenggaraan pemerintahan dan pelayanan publik di Kota Pontianak. Berikut merupakan 
Vol. 10, No. 1 (Juni 2021)

Nella Ayu Ningrum

DOI: http://dx.doi.org/10.26418/jaakfe.v10i1.46056

Hal 65-89

perkembangan Pendapatan Asli Daerah (PAD) Pemerintah Kota Pontianak Periode Tahun 2015-2019:

\section{Tabel 3}

\section{Perkembangan Pendapatan Asli Daerah Pemerintah Kota Pontianak Tahun Anggaran 2015-2019}

(dalam Rupiah)

\begin{tabular}{|c|c|c|c|}
\hline \multirow{2}{*}{ Tahun } & \multicolumn{2}{|c|}{ Pendapatan Asli Daerah } & \multirow{2}{*}{ Perubahan (\%) } \\
\cline { 2 - 3 } & Target & Realisasi & $\mathbf{9 3 , 7 3}$ \\
\hline 2015 & $357.094 .036 .232,15$ & $334.708 .368 .451,95$ & $\mathbf{9 4 , 7 2}$ \\
\hline 2016 & $411.070 .928 .094,39$ & $389.368 .654 .493,49$ & $\mathbf{9 3 , 6}$ \\
\hline 2017 & $508.574 .478 .117,00$ & $476.050 .410 .313,57$ & $\mathbf{9 1 , 9 6}$ \\
\hline 2018 & $478.866 .297 .320,84$ & $440.358 .120 .030,76$ & $\mathbf{1 0 2 , 1}$ \\
\hline 2019 & $468.923 .861 .011,48$ & $476.790 .894 .895,49$ & \\
\hline
\end{tabular}

Sumber: diolah (2020).

Berdasarkan Tabel 3 di peroleh data bahwa perkembangan Pendapatan Asli Daerah Tahun Anggaran 2015-2019 selalu mengalami peningkatan tiap tahunnya dengan presentasi kenaikan yang cukup konsisten, hal tersebut juga berbanding lurus dengan rancangan anggaran sebelum perubahan dari Pendapatan Asli Daerah dan tidak terjadi selisih yang cukup besar dari target terhadap realisasi Pendapatan Asli Daerah Kota Pontianak sehingga hal tersebut mengindikasikan bahwa pengelolaan, pengoptimalan serta pendistribusian Pendapatan Asli Daerah di Kota Pontianak cukup maksimal karena selisih angka dari target yang terealisasi tidak begitu besar. Pada Laporan Keuangan Anggaran 2019 Pemerintah Kota Pontianak total Pendapatan Asli Daerah mencapai puncaknya dengan jumlah total sebesar Rp.476.790.894.895,49 dengan presentase kenaikan sebesar 102,1\%. Namun, terjadi penurunan presentasi pencapaian atau realisasi dari tahun sebelumnya yaitu Pendapatan Asli Daerah tahun 2018 sebesar Rp.440.358.120.030,76 dengan persentase sebesar 91,96\%. Total realisasi Pendapatan Asli Daerah pada tahun 2015, 2016, 2017 secara berturut berada dalam kenaikan yang tidak signifikan yaitu pada tahun 2015 dengan jumlah total sebesar Rp.334.708.368.451,95 dengan persentase kenaikan 93,73\%. Tahun 2016 dengan jumlah total sebesar sebesar Rp 389.368.654.493,49 dengan persentase sebesar 94,72\% dan pada tahun 2017 dengan jumlah total sebesar sebesar Rp.476.050.410.313,57 dengan persentase sebesar 93,6\%,

\section{Analisis Data Retribusi Daerah Kota Pontianak (Periode Tahun 2015- 2019)}

Realisasi retribusi daerah Kota Pontianak dalam periode 5 (lima) tahun 2015- 2019 bisa dikatakan mengalami fluktuasi namun dapat dikatankan cukup terkendali meskipun realisasi masih sering terjadi selisih terhadap target anggaran sebelum perubahan namun pemerintah Kota Pontianak selalu berupaya mewujudkan target realisasi pendapatan retribusi daerah dalam menambah jumlah atau total Pendapatan Asli Daerah (PAD) Kota Pontianak yang diharapkan menjadi salah satu sumber pembiayaan penyelenggaraan pemerintah dan pembangunan untuk meningkatkan dan memeratakan kesejahteraan masyarakat. Kota Pontianak diberi peluang dalam menggali potensi sumber-sumber keuangannya dengan menetapkan jenis retribusi selain yang telah ditetapkan sepanjang kriteria yang telah ditetapkan sesuai dengan aspirasi 
Vol. 10, No. 1 (Juni 2021)

Nella Ayu Ningrum

DOI: http://dx.doi.org/10.26418/jaakfe.v10i1.46056

Hal 65-89

masyarakat. Adapun besarnya kontribusi retribusi daerah digambarkan melalui tabel berikut ini:

Tabel 4

Perkembangan Retribusi Daerah Pemerintah Kota Pontianak

Tahun Anggaran 2015-2019

(dalam Rupiah)

\begin{tabular}{|c|c|c|c|}
\hline \multirow{2}{*}{ Tahun } & \multicolumn{2}{|c|}{ Retribusi Daerah } & \multirow{2}{*}{ Perubahan $(\%)$} \\
\cline { 2 - 3 } & Target & Realisasi & $\mathbf{9 4 , 9 4}$ \\
\hline 2015 & $34.572 .370 .030,00$ & $32.821 .997 .143,00$ & $\mathbf{9 7 , 6}$ \\
\hline 2016 & $43.051 .441 .147,00$ & $42.016 .145 .122,00$ & $\mathbf{8 6 , 3 6}$ \\
\hline 2017 & $41.289 .233 .910,00$ & $35.657 .077 .655,00$ & $\mathbf{9 1 , 9 8}$ \\
\hline 2018 & $39.180 .652 .865,00$ & $36.039 .842 .255,00$ & $\mathbf{1 0 4 , 9 3}$ \\
\hline 2019 & $37.660 .825 .300,00$ & $39.515 .721 .695,00$ & \\
\hline
\end{tabular}

Sumber: diolah (2020).

Berdasarkan data pada Tabel 4 dapat diketahui bahwa pencapaian target penerimaan retribusi daerah relatif berfluktuasi pada tiap tahunnya yaitu pada tahun 2015 terealisasi sebesar 94,94\% dengan jumlah total realisasi retribusi daerah sebesar Rp. 32.821.997.143,00 dan pada tahun 2017 hanya terealisasi sebesar 86,36\% dengan jumlah total realisasi retribusi daerah sebesar Rp. 35.657.077.655,00 berarti adanya penurunan dalam merealisasi retribusi daerah.

Relatif rendahnya persentase realisasi penerimaan relatif befluktuasi, peningkatan tertinggi terjadi pada tahun 2019 sebesar 104,93\% dengan jumlah total realisasi retribusi daerah sebesar Rp. 39.515.721.695,00 sedangkan pada tahun 2016 terealisasi sebesar 97,6\% dengan jumlah total realisasi retribusi daerah sebesar Rp. 42.016.145.122,00 dan tahun 2018 terealisasi sebesar 91,98\% dengan jumlah total realisasi retribusi daerah sebesar Rp. 36.039.842.255,00. Pencapaian target penerimaan retribusi yang berfluktuasi adalah disebabkan terlalu tinggi menetapkan target dan kurang memperhitungkan potensi penerimaan retribusi tersebut.

Perhitungan Kontribusi Retribusi Daerah sebagai Sumber Pendapatan Asli Daerah Pemerintah Kota Pontianak (Periode Tahun 2015-2019)

Retribusi daerah adalah pembayaran terhadap jasa yang telah diberikan oleh pemerintah daerah dan diatur berdasarkan peraturan daerah masing-masing. Hasil dari pemungutan yang telah dilakukan akan digunakan untuk membiayai rumah tangga daerah. Retribusi daerah merupakan salah satu faktor penentu tingkat Pendapatan Asli Daerah dan juga merupakan salah satu indikator penting yang dinilai sebagai tingkat kemandirian pemerintah daerah di bidang keuangan. Semakin tinggi peran retribusi daerah terhadap Pendapatan Asli Daerah dalam Anggaran Pendapatan dan Belanja Daerah (APBD), akan mencerminkan keberhasilan usaha atau tingkat kemampuan daerah dalam pembiayaan dan penyelenggaraan pembangunan serta pemerintahan. Peningkatan jumlah retribusi daerah dan pengelolaan Pendapatan Asli Daerah juga akan menjamin pelaksanaan fungsi-fungsi pemerintahan daerah yaitu pengaturan, pelayanan, dan pemberdayaan dapat berjalan secara efektif apabila kemampuan fiskal atau retribusi dari daerah tersebut dikelola dengan baik. Dengan demikian, apabila Pendapatan Asli Daerah semakin meningkat dari tahun ke tahun akan semakin mengurangi ketergantungan pemerintah daerah terhadap bantuan dana dari pusat dan juga daerah semakin leluasa dalam 
Vol. 10, No. 1 (Juni 2021)

Nella Ayu Ningrum

DOI: http://dx.doi.org/10.26418/jaakfe.v10i1.46056

Hal 65-89

membelanjakan penerimaan mereka sesuai dengan prioritas pembangunan daerah mereka. Salah satu retribusi daerah yang sangat besar pengaruhnya terhadap pemasukan kas daerah adalah retribusi jasa umum yaitu retribusi pelayanan kesehatan, retribusi pelayanan persampahan atau kebersihan, retribusi penggantian biaya cetak Kartu Tanda Penduduk dan akta catatan sipil serta retribusi pelayanan parkir di tepi jalan umum.

Untuk mengetahui seberapa besar penerimaan daerah yang berasal dari retribusi daerah, berikut ini rekapitulasi data Pendapatan Asli Daerah dan Retribusi Daerah yang diambil dari tahun 2015-2019 termuat dalam daftar lampiran 1-5:

Tabel 5

Rekapitulasi Target dan Realisasi Retribusi Daerah Pemerintah Kota Pontianak (Periode Tahun 2015-2019)

(dalam Rupiah)

\begin{tabular}{|c|c|c|}
\hline Tahun & Target Retribusi & Realisasi Retribusi \\
\hline 2015 & $34.572 .370 .030,00$ & $32.821 .997 .143,00$ \\
\hline 2016 & $43.051 .441 .147,00$ & $42.016 .145 .122,00$ \\
\hline 2017 & $41.289 .233 .910,00$ & $35.657 .077 .655,00$ \\
\hline 2018 & $39.180 .652 .865,00$ & $36.039 .842 .255,00$ \\
\hline 2019 & $37.660 .825 .300,00$ & $39.515 .721 .695,00$ \\
\hline
\end{tabular}

Sumber: diolah (2020).

Dari Tabel 5 diatas dapat dilihat realisasi dan target penerimaan retribusi daerah mengalami fluktuasi dari tahun ke tahun. Pada tahun 2015 target retribusi daerah mencapai Rp34.572.370.030,00, tahun 2016 target retribusi mengalami kenaikan menjadi Rp43.051.441.147,00, tahun 2017, 2018 dan 2019 target retribusi turun berturut-turut menjadi Rp41.289.233.910,00, Rp39.180.652.865,00, dan Rp. 37.660.825.300,00. Sedangkan pada realisasinya tahun 2015 mencapai Rp32.821.997.143,00 pada tahun 2016 realisasi retribusi mengalami kenaikan menjadi Rp42.016.145.122,00, tahun 2017, 2018, dan 2019 mengalami kenaikan berturut-turut menjadi Rp35.657.077.655,00, Rp36.039.842.255,00, dan Rp39.515.721.695,00.

Tabel 6

Rekapitulasi Realisasi Retribusi Daerah dan Pendapatan Asli Daerah Pemerintah Kota Pontianak (Periode Tahun 2015-2019)

(dalam Rupiah)

\begin{tabular}{|c|c|c|}
\hline Tahun & Kontribusi Retribusi & Pendapatan Asli Daerah \\
\hline 2015 & $32.821 .997 .143,00$ & $334.708 .368 .451,95$ \\
\hline 2016 & $42.016 .145 .122,00$ & $389.368 .654 .493,49$ \\
\hline 2017 & $35.657 .077 .655,00$ & $476.050 .410 .313,57$ \\
\hline 2018 & $36.039 .842 .255,00$ & $440.358 .120 .030,76$ \\
\hline 2019 & $39.515 .721 .695,00$ & $476.790 .894 .895,49$ \\
\hline
\end{tabular}

Sumber: Dikembangkan penulis dari Laporan Realisasi Anggaran Pendapatan dan Belanja Pemerintah Kota Pontianak Tahun 2015-2019 atau dalam masa periode 5 
Vol. 10, No. 1 (Juni 2021)

Nella Ayu Ningrum

DOI: http://dx.doi.org/10.26418/jaakfe.v10i1.46056

Hal 65-89

(lima) tahun untuk kebutuhan penelitian (2020).

Dari Tabel 6 di atas dapat dilihat realisasi Pendapatan Asli Daerah pada tahun 2015 mencapai Rp334.708.368.451,95 dan mengalami kenaikan pada tahun 2016 dan 2017 yaitu Rp389.368.654.493,49 dan Rp476.050.410.313,57. Namun kembali mengalami penurunan pada tahun 2018 yaitu sebesar Rp440.358.120.030,76 dan pada tahun 2019 naik menjadi Rp476.790.894.895,49.

Berdasarkan uraian tersebut penerimaan retribusi di Kota Pontianak dalam jangka waktu 5 tahun antara tahun 2015-2019 mengalami fluktuasi. Dalam hal ini dengan penerimaan retribusi daerah yang berfluktuasi dapat mempengaruhi Pendapatan Asli Daerah (PAD) di Kota Pontianak. Langkah untuk mengetahui berapa kontribusi retribusi daerah dalam Pendapatan Asli Daerah dapat dihitung dengan menggunakan rumus berikut (Mahmudi, 2005):

$$
\text { Kontribusi PAD }=\frac{\text { Kontribusi Retribusi }}{P A D} \times 100 \%
$$

Dimana hasil pertahunnya sebagai berikut:

Tahun $2015=\frac{32.821 .997 .143,00}{334.708 .368 .451,95} \times 100 \%=9,80614775 \%$ atau $9,81 \%$

Tahun $2016=\frac{42.016 .145 .122,00}{389.368 .654 .493,49} \times 100 \%=10,79083913 \%$ atau $10,79 \%$

Tahun $2017=\frac{35.657 .077 .655,00}{476.050 .410 .313,57} \times 100 \%=7,49018946 \%$ atau $7,49 \%$

Tahun $2018=\frac{36.039 .842 .255,00}{440.358 .120 .030,76} \times 100 \%=8,18421203 \%$ atau $8,18 \%$

Tahun $2019=\frac{39.515 .721 .695,00}{476.790 .894 .895,49} \times 100 \%=8,2878515 \%$ atau $8,29 \%$

Dana bagi hasil retribusi dalam memberikan kontribusi dapat diketahui melalui kategori baik apabila rasio yang dicapai minimal 50\%. Pengukuran nilai kontribusi Retribusi Daerah Pemerintah Kota Pontianak secara terperinci yaitu ke dalam 6 (enam) tingkat sebagai berikut:

Tabel 7

Kontribusi Retribusi Daerah Terhadap Pendapatan Asli Daerah Pemerintah Kota Pontianak (Periode Tahun 2015-2019)

\begin{tabular}{|c|c|c|}
\hline Tahun & Kontribusi & Kriteria \\
\hline 2015 & $9,81 \%$ & Sangat Kurang \\
\hline 2016 & $10,79 \%$ & Kurang \\
\hline 2017 & $7,49 \%$ & Sangat Kurang \\
\hline 2018 & $8,18 \%$ & Sangat Kurang \\
\hline 2019 & $8,29 \%$ & Sangat Kurang \\
\hline Rata-Rata & $\mathbf{8 , 9 1 \%}$ & Sangat Kurang \\
\hline
\end{tabular}

Sumber: Diolah (2020).

Apabila digambarkan dalam bentuk grafik, maka dapat dihasilkan grafik dari Kontribusi Retribusi Daerah Terhadap Pendapatan Asli Daerah Pemerintah Kota Pontianak (Periode Tahun 2015-2019) sebagai berikut: 
Vol. 10, No. 1 (Juni 2021)

Nella Ayu Ningrum

DOI: http://dx.doi.org/10.26418/jaakfe.v10i1.46056

Hal 65-89

\section{Gambar 1}

\section{Grafik Kontribusi Retribusi Daerah Terhadap Pendapatan Asli Daerah Pemerintah} Kota Pontianak (Periode Tahun 2015-2019)

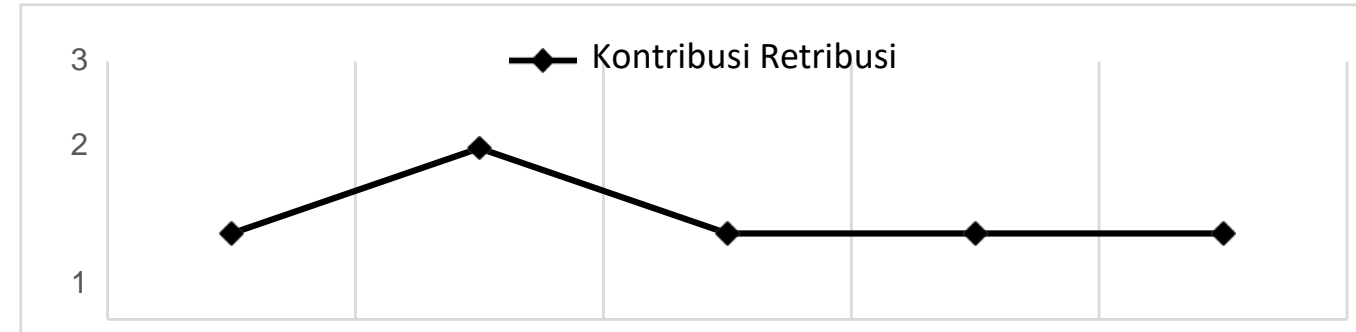

TAHUN 2015 TAHUN 2016 TAHUN 2017 TAHUN 2018 TAHUN 2019

Sumber: diolah (2020).

Catatan:

- Keterangan sumbu x menunjukkan periode 5 (lima) tahun yaitu tahun 2015- 2019.

- Keterangan sumbu y menunjukkan bahwa; 1 = Sangat Kurang; 2 = Kurang; 3 = Sedang, 4 = Cukup Baik, $5=$ Baik, dan $6=$ Sangat Baik.

\section{Perhitungan Tingkat Efektivitas Penerimaan Retribusi Daerah Pemerintah Kota Pontianak (Periode 2015-2019)}

Efektivitas retribusi daerah menunjukkan kemampuan pemerintahan daerah dalam mengumpulkan retribusi daerah sesuai dengan jumlah penerimaan retribusi daerah yang ditargetkan. Efektivitas retribusi daerah merupakan perbandingan antara realisasi dan target penerimaan retribusi daerah, sehingga dapat digunakan sebagai ukuran keberhasilan dalam melakukan pungutan. Perhitungan Rasio Efektivitas dapat menggunakan rumus sebagai berikut (Halim, 2008:93):

$$
\text { Efektivitas }=\frac{\text { Realisasi Penerimaan Retribusi }}{\text { Target Penerimaan Retribusi }} \times 100 \%
$$

Dimana hasil pertahunnya sebagai berikut:

Tahun $2015=\frac{32.821 .997 .143,00}{34.572 .370 .030,00} \times 100 \%=94,93707581 \%$ atau $94,94 \% \%$

Tahun $2016=\frac{42.016 .145 .122,00}{43.051 .441 .147,00} \times 100 \%=97,59521169 \%$ atau $97,60 \%$

Tahun $2017=\frac{35.657 .077 .655,00}{41.289 .233 .910,00} \times 100 \%=6,35926191 \%$ atau $86,36 \%$

Tahun $2018=\frac{36.039 .842 .255,00}{39.180 .652 .865,00} \times 100 \%=91,98377163 \%$ atau $91,98 \%$

Tahun $2019=\frac{39.515 .721 .695,00}{37.660 .825 .300,00} \times 100 \%=104,92526752 \%$ atau $104,93 \%$

Dalam perhitungan efektivitas apabila yang dicapai minimal satu atau $100 \%$ maka rasio efektivitas semakin baik artinya semakin efektif. Demikian pula sebaliknya, apabila semakin kecil persentase efektivitasnya maka semakin tidak efektif (Halim, 2008:93). Adapun kriteria efektivitasnya yaitu sebagai berikut: 
Vol. 10, No. 1 (Juni 2021)

Nella Ayu Ningrum

DOI: http://dx.doi.org/10.26418/jaakfe.v10i1.46056

Hal 65-89

Tabel 8

Tingkat Efektivitas Penerimaan Retribusi Daerah

Pemerintah Kota Pontianak (Periode Tahun 2015-2019)

(dalam Rupiah)

\begin{tabular}{|c|c|c|c|c|}
\hline Tahun & Target & Realisasi & $\begin{array}{l}\text { Persentase } \\
\text { Efektivitas }\end{array}$ & $\begin{array}{c}\text { Tingkat } \\
\text { Efektivitas }\end{array}$ \\
\hline 2015 & $34.572 .370 .030,00$ & $32.821 .997 .143,00$ & $94,94 \%$ & Efektif \\
\hline 2016 & $43.051 .441 .147,00$ & $42.016 .145 .122,00$ & $97,60 \%$ & Efektif \\
\hline 2017 & $41.289 .233 .910,00$ & $35.657 .077 .655,00$ & $86,36 \%$ & Cukup Efektif \\
\hline 2018 & $39.180 .652 .865,00$ & $36.039 .842 .255,00$ & $91,98 \%$ & Efektif \\
\hline 2019 & $37.660 .825 .300,00$ & $39.515 .721 .695,00$ & $104,93 \%$ & Sangat Efektif \\
\hline \multicolumn{3}{|c|}{ Rata-Rata } & $95,16 \%$ & Efektif \\
\hline
\end{tabular}

Sumber: Dikembangkan penulis untuk kebutuhan penelitian (2020).

Dilihat dari target dan realisasi retribusi daerah kota Pontianak pada Tabel tersebut, efektivitas retribusi pada tahun 2015 dan 2016 termasuk dalam kriteria efektif dengan persentase efektivitas sebesar 94,94\% dan 97,60\%, pada tahun 2017 termasuk dalam kriteria cukup efektif dengan persentase efektivitas sebesar 86,36\%, dan tahun 2018 termasuk dalam kriteria efektif dengan persentase efektivitas sebesar 91,98\% dan tahun 2019 termasuk dalam kriteria sangat efektif dengan persentase efektivitas sebesar 104,93\%, meskipun mengalami fluktuasi dalam lima tahun (2015-2019) retribusi daerah termasuk dalam kriteria efektif dengan rata-rata persentase efektivitasnya sebesar 95,16\%. Apabila digambarkan dalam bentuk grafik, maka dapat dihasilkan grafik dari efektivitas penerimaan retribusi daerah Pemerintah Kota Pontianak (Periode Tahun 2015-2019) sebagai berikut:

Gambar 2

Grafik Tingkat Efektivitas Penerimaan Retribusi Daerah Pemerintah Kota Pontianak (Periode Tahun 2015-2019)

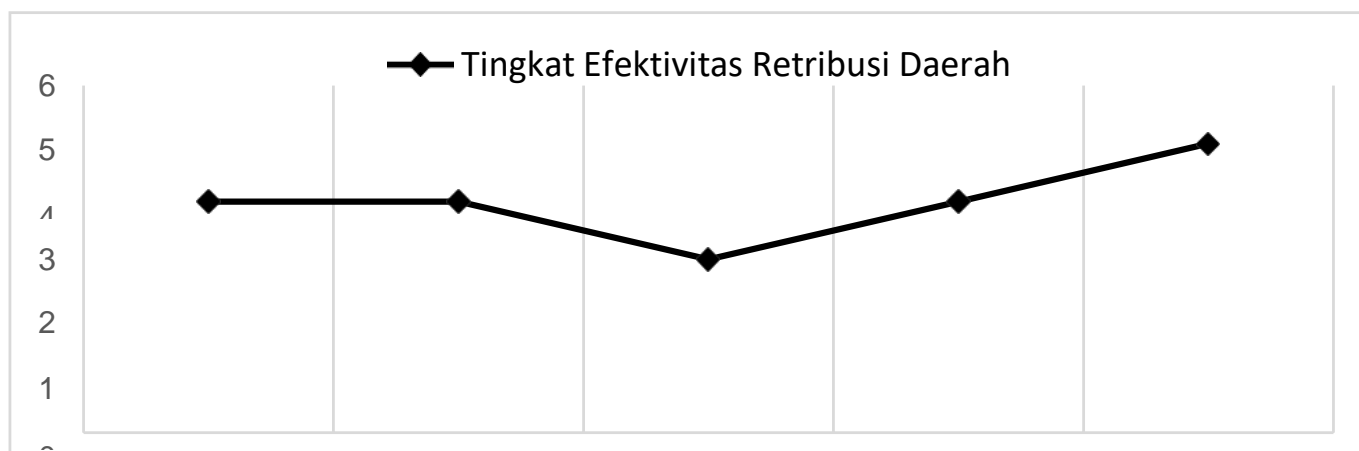

TAHUN 2015 TAHUN 2016 TAHUN 2017 TAHUN 2018 TAHUN 2019

Sumber: Dikembangkan penulis untuk kebutuhan penelitian (2020).

Catatan:

- Keterangan sumbu x menunjukkan periode 5 (lima) tahun yaitu tahun 2015- 2019.

- Keterangan sumbu y menunjukkan bahwa; 1 = Tidak Efektif; 2 = Kurang Efektif; 3 = Cukup Efektif; 4 = Efektif; dan 5 = Sangat Efektif. 
Vol. 10, No. 1 (Juni 2021)

Nella Ayu Ningrum

DOI: http://dx.doi.org/10.26418/jaakfe.v10i1.46056

Hal 65-89

Naik turunnya retribusi daerah tentunya secara langsung maupun tidak langsung akan mempengaruhi total Pendapatan Asli Daerah (PAD) Kota Pontianak, meskipun masih terdapat komponen pendapatan Asli Daerah Lainnya. Namun, retribusi daerah memberi sumbangsih yang besar dan berpengaruh terhadap total Pendapatan Asli Daerah Kota Pontianak.

\section{KESIMPULAN DAN SARAN \\ Kesimpulan}

Berdasarkan hasil tinjauan atas retribusi daerah terhadap Pendapatan Asli Daerah Pemerintah Kota Pontianak, dapat ditarik kesimpulan sebagai berikut:

1. Dalam periode lima tahun (2015-2019) retribusi Pemerintah Kota Pontianak mengalami fluktuasi target dan penurunan realisasi. Pada 2015 menunjukkan sebesar 9,81\%, meskipun seperti itu berbeda dengan pengaruhnya terhadap Pendapatan Asli Daerah yang ternyata mengalami peningkatan dengan nilai paling tinggi dalam 5 (lima) periode yaitu 10,79\%. Namun pada tahun 2017 mengalami penurunan yang sangat pesat yang hanya mendapatkan 7,49\% saja. Kendati demikian berangsur mulai terdapat peningkatan di tahun 2018-2019 secara berturut-turut yaitu 8,18\% dan 8,29\% Dalam periode 5 (lima) tahun pengaruh retribusi terhadap Pendapatan Asli Daerah mendapatkan rata-rata 8,91\% dari 100\% Pendapatan Asli Daerah yang didapat. Hal ini membuktikan bahwa91,09\% dari Pendapatan Asli Daerah yang didapat berasal dari pendapatan pajak daerah, pendapatan hasil pengelolaan kekayaan daerah yang dipisahkan, dan juga Pendapatan Asli Daerah dari lain-lain yang sah. Retribusi daerah mengalami fluktuasi target dan penurunan realisasi pada tahun 2017. Meskipun terdapat peningkatan pada tahun 2018-2019 rata-rata kontribusi retribusi masih termasuk dalam kategori sangat kurang.

2. Dilihat dari target dan realisasi retribusi daerah kota Pontianak efektivitas retribusi pada tahun 2015-2016 termasuk dalam kriteria efektif, pada tahun 2017 termasuk dalam kriteria cukup efektif, dan tahun 2019 termasuk dalam kriteria sangat efektif, meskipun mengalami fluktuasi dalam lima tahun (2015-2019) retribusi daerah termasuk dalam kriteria efektif.

\section{Saran}

Dari hasil pembahasan atas tinjauan retribusi daerah terhadap Pendapatan Asli Daerah Pemerintah Kota Pontianak, beberapa saran yang dapat penulis berikan yaitu:

1. Bagi Instansi Terkait

Pemerintah daerah setempat khususnya Kota Pontianak harus melakukan peninjauan lebih lanjut tentang retribusi daerah dimulai dari sistem, pekerja, dan juga mengajak warga daerah untuk lebih sadar dan turut berpartisipasi terhadap retribusi agar penerimaan yang didapat bisa terus dilaksanakan dengan baik. Meskipun pembangunan kota Pontianak sudah banyak mengalami kemajuan tetapi tetap saja penerimaan retribusi juga suatu hal yang penting untuk kemajuan daerah kota Pontianak yang mungkin kedepannya menjadi daerah untuk penerapan retribusi terbaik.

2. Bagi Peneliti Selanjutnya

Bagi peneliti selanjutnya diharapkan dapat melakukan penelitian terhadap retribusi untuk tahun-tahun kedepannya secara teliti dan dapat menginformasikan mengenai spesifikasi dari retribusi, seperti mengetahui tarif retribusi dari beberapa instansi kedinasan yang berada di Kota Pontianak, serta dapat membandingkan pengaruh dan efektivitas antara retribusi Kota Pontianak dan 
Vol. 10, No. 1 (Juni 2021)

Nella Ayu Ningrum

DOI: http://dx.doi.org/10.26418/jaakfe.v10i1.46056

Hal 65-89

retribusi dari luar Kota Pontianak.

\section{DAFTAR PUSTAKA}

Asteria, B., (2015). Analisis Pengaruh Penerimaan Pajak Daerah dan Retribusi Daerah Terhadap Pendapatan Asli Daerah Kabupaten/Kota di Jawa Tengah. Jurnal Riset Manajemen STIE Widya Wiwaha, 51-61.

Badan Pusat Statistik. (2020). Realisasi Pendapatan Daerah Otonom Kota Pontianak, 20162017 Actual Autonomous Income of Pontianak Municipality, 2016-2017. Pontianak: Badan Pusat Statistik.

Bawuna, N. N., Kalangi, L., \& Runtu, T., (2016). Analisis Efektivitas Kinerja Penerimaan Pajak Daerah dan Retribusi Daerah Terhadap Pendapatan Asli Daerah di Kabupaten Siau Tagulandang Biaro. Jurnal Ilmiah Berkala Efisiensi Universitas Sam Ratulangi, 593-603.

Dwiastuti, N., (2018). Efektivitas Penerimaan Retribusi Daerah Terhadap Pendapatan Asli Daerah Kabupaten/Kota di Provinsi Kalimantan Barat. Prosiding SATIESPE 2018. Pontianak, Indonesia: Universitas Tanjungpura.

Ersita, M., \& Elim I., (2016). Analisis Efektivitas Penerimaan Retribusi Daerah dan Kontribusinya Terhadap Peningkatan Pendapatan Asli Daerah di Provinsi Sulawesi Utara. Jurnal EMBA Universitas Sam Ratulangi, 889-897.

Ferdiansyah, F., (2018). Analisis Efektivitas Penerimaan Pajak Daerah, Retribusi Daerah dan Kontribusinya Terhadap Peningkatan Pendapatan Asli Daerah (Studi pada Badan Pengelolaan Pajak Daerah Kota Palembang 2012-2016). Jurnal Universitas Sriwijaya, 132.

Handoko, S., (2013). Analisis Tingkat Efektivitas Pajak Daerah sebagai Sumber Pendapatan Asli Daerah Kota Pontianak. Jurnal Ilmiah Magister Ekonomi Universitas Tanjungpura, $1-17$.

Kusuma, M. K. A. A., \& Wirawati, N. G. P., (2013). Analisis Pengaruh Penerimaan Pajak Daerah dan Retribusi Daerah Terhadap Peningkatan Pendapatan Asli Daerah SeKabupaten/Kota di Provinsi Bali. E-Jurnal Akuntansi Universitas Udayana, 574-585.

Lakoy, T. W., Engka, D. S. M., \& Tumangkeng, S. Y. L., (2016). Kontribusi dan Pengaruh Penerimaan Retribusi Daerah Terhadap Pendapatan Asli Daerah di Kabupaten Minahasa Selatan (2005-2014). Jurnal Berkala Ilmiah Efisiensi Universitas Sam Ratulangi, 559567.

Laksmi, D. N., (2016). Kontribusi Komponen Pendapatan Asli Daerah (PAD) Terhadap Realisasi Pendapatan Asli Daerah (PAD) Tahun Anggaran 2006- 2015 Kota Magelang. Jurnal Universitas Negeri Yogyakarta, 1-89.

Marselina B. E., (2013). Analisis Kontribusi Pajak Parkir dan Retribusi Pasar Terhadap Pendapatan Asli Daerah Pada Pemerintah Kota Padang. Jurnal Universitas Negeri Padang, 1-23.

Mauri A. P., Mattalatta, Hasmin., (2017). Analisis Pengaruh Penerimaan Retribusi Daerah dan Pajak Daerah Terhadap Peningkatan Pendapatan Asli Daerah Pada Kabupaten Soppeng. Jurnal Mirai Management STIE Amkop Makassar, 175-193.

Murniati S., Kasasih, D., (2017). Analisis Kontribusi dan Efektivitas Penerimaan Retribusi Pelayanan Pasar Terhadap Pendapatan Asli Daerah (PAD) Daerah Kota Palembang. Jurnal Kompetitif Universitas Tridinanti Palembang, 85- 109.

Putriani, E., (2016). Pengaruh Retribusi Daerah Terhadap Pendapatan Asli Daerah (PAD) Kabupaten Bulukumba. Jurnal Universitas Islam Negeri Alauddin Makassar, 1-106. 
Vol. 10, No. 1 (Juni 2021)

Nella Ayu Ningrum

DOI: http://dx.doi.org/10.26418/jaakfe.v10i1.46056

Hal 65-89

Ponto, C. D., Karamoy, H., \& Runtu, T., (2015). Analisis penerapan Sistem dan Prosedur Pemungutan Pajak Hiburan di Kota Bitung. Jurnal Universitas Sam Ratulangi Manado, $1-13$.

Peraturan Wali Kota Nomor 25 Tahun 2019, tentang Masterplan Pontianak Smart City Tahun 2019-2028

Rahmadani A., (2018) Pengaruh Retribusi Daerah Terhadap Pendapatan Asli Daerah Kabupaten Batu Bara (Studi Kasus Badan Pengelolaan Pajak dan Retribusi Daerah Kabupaten Batu Bara). Jurnal Akuntansi Syariah Universitas Islam Negeri Sumatera Utara, 1-73.

Republik Indonesia. Undang-Undang Nomor 33 Tahun 2004, tentang Pemerintah Daerah -. Undang-Undang Nomor 23 Tahun 2014, tentang Pemerintahan Daerah -. Undang-Undang Nomor 28 Tahun 2009, tentang Perimbangan Keuangan antara Pusat dan Daerah pasal 1 angka 18 --. Undang-Undang Nomor 28 Tahun 2009, tentang Pajak Daerah dan Retribusi Daerah pasal 1 ayat 10

-------------. Undang-Undang Nomor 23 Tahun 2014, tentang Pemerintahan Daerah

Safrita, (2011). Pengaruh Retribusi Daerah Terhadap Pendapatan Asli Daerah Kota Jayapura. Jurnal Universitas Yapis Papua, 114-102.

Sarno, (2012). Analisis Potensi dan Realisasi Pendapatan Asli Daerah dalam Mencapai Kemandirian Keuangan Daerah di Kabupaten Sekadau Tahun 2006-2011. Jurnal Universitas Tanjungpura

Sitinjak, N. D., (2016). Tinjauan Pajak Daerah dan PDRB atas Efektivitas dan Kontribusinya Terhadap Pendapatan Asli Daerah Kota Madiun. Jurnal Universitas Merdeka Malang, 17.

Temaja, I. D. G. A D., \& Saputra, I. D. G. D., (2014) Pengaruh Retribusi Pelayanan Pasar, Pajak Hotel dan Restoran pada Pendapatan Asli Daerah Kabupaten Gianyar. E-Jurnal Akuntansi Universitas Udayana, 209-220.

Toduho, D. A. M., Saerang, D. P. E, \& Elim A., (2014). Penerimaan Retribusi Pasar dalam Upaya Meningkatkan Pendapatan Asli Daerah Kota Tidore Kepulauan. Jurnal AkuntansiEMBA, 1090-1103

Tresnawati, R., \& Putri, E. A., (2017). Tinjauan atas Retribusi Daerah Terhadap Pendapatan Asli Daerah Pemerintah Kota Bandung. Jurnal Akuntansi Riset (ASET) Universitas Widyatama Bandung, 73-80.

Umbas, B. R., Nangoi, G. B., \& Tirayoh, V., (2018). Analisis Pengelolaan Dan Kontribusi Penerimaan Retribusi Pelayanan Kesehatan Terhadap Pendapatan Asli Daerah Di Kabupaten Minahasa Utara. Jurnal Riset Akuntansi Going Concern Universitas Sam Ratulangi, 796-803.

Widyaningsih, A., \& Srimartina, A., (2007). Analisis Sumber-Sumber Pendapatan Asli Daerah Terhadap Pendapatan Asli Daerah di Kabupaten/Kota Wilayah Provinsi Jawa Barat. Jurnal Akuntansi Riset (ASET) Universitas UPI, 388- 399.

Yuliastuti, I. A. N., \& Dewi, N. L. P. S., (2017). Analisis Efektivitas dan Kontribusi Retribusi Daerah Terhadap Pendapatan Asli Daerah Kota Denpasar. Jurnal Riset Akuntansi (JUARA) Universitas Mahasaraswati Denpasar, 91-102.

Zahari, M., (2016). Pengaruh Pajak dan Retribusi Daerah Terhadap Pendapatan Asli Daerah. Jurnal Universitas Batanghari. 133-148 